Review Article

\title{
Calcium antagonists and chronic cardiac failure
}

\author{
M.J. Kendall, R.C. Horton and S.R. Smith
}

Department of Therapeutics and Clinical Pharmacology, Medical School, Edgbaston, Birmingham 15, UK.

The treatment of cardiac failure involves a series of steps, which are taken in an order determined by clinical necessity. In some instances there is a treatable cause which may be amenable to appropriate medical or surgical management. In many there are correctable factors exacerbating the situation, for example high blood pressure, anaemia, arrhythmias, high salt intake or drugs such as beta-blockers. More specific treatment includes rest and diuretics, with or without digoxin. If these measures prove insufficient, the next step is to add a vasodilator. There are a number of vasodilators available with only preliminary information on their relative merits (Lipkin \& Poole-Wilson, 1985). The calcium antagonists are one group of vasodilators but they have other actions which may make them an attractive choice in a patient with resistant heart failure.

Most patients with chronic cardiac failure have either ischaemic heart disease, hypertension or longstanding chest disease with pulmonary hypertension, as the major underlying cause of their heart disease. Calcium antagonists have the potential to ameliorate each of these three underlying disorders. In patients with coronary artery disease calcium antagonists will dilate the coronary arteries (Bourassa et al., 1980), reduce spasm (Antman et al., 1980) and improve flow by their effects on platelets (Dale et al., 1983) and red cells (Waller et al., 1984). Calcium antagonists reduce heart work (Ellrodt et al., 1980) and have an antiarrhythmic effect (Fagbemi \& Parratt, 1981). There is ample evidence that these actions are effective since calcium antagonists have repeatedly been shown to help patients with angina (Subramanian et al., 1982; Gerstenblith et al., 1982; Theroux et al., 1982). These drugs have also established a major place in the treatment of systemic hypertension (Hornung et al., 1983; Buhler et al., 1982). Their role in pulmonary hypertension is much less clearly defined but it is possible that they do reduce pressure in the pulmonary vascular bed (Sturani et al., 1984; Packer, 1985).

In addition to their effect on the underlying disor-

Correspondence: M.J. Kendall, M.D., F.R.C.P.

Accepted: 10 February 1986 der, calcium antagonists correct the disturbed haemodynamic state which occurs in cardiac failure. This state consists of (1) reduced cardiac output, (2) compensatory tachycardia, vasoconstriction and fluid retention and (3) cardiac dilatation and hypertrophy. The body responds to a fall in blood pressure by increasing sympathetic drive which produces the tachycardia, vasoconstriction and renin release. The latter, together with other less well defined processes, causes fluid retention. These responses may help the patient with hypotension due to blood loss but the patient with serious cardiac disease is faced with 3 events which all increase heart work. In addition, tissue perfusion decreases. The cardiac enlargement which occurs may initially have a beneficial effect and improve cardiac output but eventually these structural changes lead to an increase in heart work and exacerbate the problems associated with a defective coronary circulation. The aims of treatment are therefore to improve cardiac output and hopefully to correct the counterproductive responses both functional and structural.

Calcium antagonists have 3 major actions which might enable them to achieve the aims of treatment just defined. Firstly, they relax arterial smooth muscle (Katz et al., 1984; Opie, 1984) and thereby dilate arteries and reduce peripheral resistance. Secondly, they reduce myocardial contractility in the same way by modifying the cellular intake of calcium which is a major stimulus to cardiac muscle contraction (Katz et al., 1984; Opie, 1984). Thirdly, they influence the conducting system in the heart and in particular they delay transmission in the A-V node (Clusin et al., 1982; Opie, 1984). Of these, it is the vasodilatation which is most important but all three may contribute to the twin objectives of achieving increased cardiac output and a reduction in heart work. The output of a pump can be increased by reducing the impedance to flow. In relation to the heart the impedance is predominantly determined by systemic arteriolar tone or resistance but also by blood viscosity and by blood volume. The arterial vasodilatation produced by calcium antagonists is therefore of paramount importance but their effects on red cells which reduce the 
viscosity of the blood (Waller et al., 1984) and their natriuretic effects (Bell \& Lindner, 1984; Johns, 1985) probably also assist. These changes will not only increase cardiac output but also reduce heart work. The effects of calcium antagonists on $\mathrm{A}-\mathrm{V}$ conduction may help by preventing the development of a reflex tachycardia which may occur when a simple arterial vasodilator is given.

Hitherto calcium antagonists have been referred to as if the drugs were chemically similar agents which all acted in the same way. In reality the three drugs nifedipine, diltiazem and verapamil are chemically and pharmacodynamically distinct (Opie, 1984; Spedding, 1985) with differing potentials for use in heart failure. Furthermore some of the many new calcium antagonists currently undergoing clinical evaluation may prove particularly useful for this indication. The published data currently available on their efficacy is limited and comparative studies designed to assess their place in treatment of heart failure are virtually non-existent. Nevertheless these drugs are being used for resistant cardiac failure; it is therefore desirable to know the evidence on which this practice is based.

\section{Nifedipine}

There are in fact many acute haemodynamic studies which have purported to show the reduction in preload and afterload produced by sublingual nifedipine (Matsui et al., 1979; Matsumoto et al., 1980; Elkayam et al., 1985). The results of these studies must be considered encouraging but most cannot be considered adequate, controlled clinical trials. A study by Ludbrook and colleagues (1982), which was randomized and single blind, involved 13 patients with heart failure given placebo whilst 19 received $20 \mathrm{mg}$ nifedipine. In those on nifedipine there was a significant reduction in afterload and myocardial oxygen requirements with significant increases in ejection fraction and cardiac output. Placebo treatment did not produce any improvements. Acute studies have also demonstrated that nifedipine has a beneficial effect in exercise and may improve oxygen supply/demand ratios (Magorien et al., 1984).

Chronic studies in patients with heart failure tend to be difficult to perform and to interpret since the patients are not only ill but usually elderly and on other medication. Occasional lack of success and some deaths are therefore inevitable. Not surprisingly therefore chronic administration studies have yielded conflicting results. Guazzi and colleagues (1984), for example, gave nifedipine to 15 patients with failing left ventricles due to long standing hypertension. They achieved a reduction in vascular resistance and an improvement in dyspnoea. This confirmed the results of an earlier investigation (Bellocci et al., 1981) in which 8 patients with refractory heart failure (NYHA 3 and 4) were given nifedipine over a 2 month period and a significant reduction in vascular resistance and an increase in cardiac index were achieved and maintained $(P<0.001)$. On the other hand Brooks and colleagues (1980) reported that 2 of their 6 patients with heart failure deteriorated and Elkayam et al. (1983) found little clinical benefit using nifedipine in their 11 cardiac failure patients.

\section{Verapamil}

Verapamil has established for itself a major place in the treatment of cardiac arrhythmias and is a drug of first choice in the treatment of supraventricular tachycardia (Schamroth, 1980). However, it is also an effective antihypertensive drug (Gould et al., 1982) with a different side effect profile from nifedipine, and it controls angina (Boutles et al., 1983). It has to be used cautiously with beta-blockers and must never be given intravenously to a beta-blocked patient.

Verapamil has been used to treat heart failure but care is needed to build the dose up to the required level since too large a dose may cause negative inotropic effects. Rosing and colleagues (1981) used increasing doses up to a maximum of $120 \mathrm{mg} \mathrm{6-8}$ hourly in 78 patients with hypertrophic cardiomyopathy and achieved symptomatic improvement in 42 (in 25 of these by at least one NYHA class). Treatment had to be curtailed in 6 because of adverse haemodynamic? and conduction defects. In two studies in which verapamil was given intravenously (Ferlinz et al., 1979; Ferlinz \& Citron, 1983) systemic vascular resistance was reduced in a total of 34 patients with heart failure and indications of left ventricular performance improved. Unfortunately if larger doses are used in patients with more severely compromised left ventricular function, heart failure may be made worse (Chew et al., 1981). Dose is clearly critical (Kates et al., 1981).

The haemodynamic risks of verapamil may be counterbalanced by the potential benefits which derive from its anti-arrhythmic actions. Many patients with chronic cardiac failure die suddenly (Franciosa et al., 1983). Some of these are presumed to be associated with ischaemic ventricular tachyarrhythmias which may be suppressed by verapamil (Clusin et al., 1982).

\section{Diltiazem}

This is often considered a relatively new calcium antagonist but it has been used extensively for many years particularly in Japan but also in the United States. It is believed to be a good coronary vasodilator which is effective in the treatment of angina (Petru et 
al., 1983) and can be used with beta-blockers (Strauss \& Parisi, 1985; Johnston et al., 1985) indicating that it has less cardiodepressant action than verapamil.

Walsh and colleagues (1982) have demonstrated clinical and haemodynamic improvements in six patients with ischaemic heart failure when they were treated with intravenous followed by oral diltiazem (120 mg three times daily). Materne et al. (1984) also have experience of intravenous diltiazem. They used larger doses and recommended caution as bradycardia may occur if too large a dose is given.

\section{New calcium antagonists}

The three drugs described above are the first generation of drugs that act by calcium antagonism. There are many more being evaluated and several more generations can be expected. Some of these which have relatively little negative inotropic action, sufficient effect on the A-V node or other actions to prevent the development of compensatory tachycardias and potent vasodilatory effects on both peripheral and coronary arteries may prove even more effective in the treatment of heart failure. Felodipine for example appears to have a greater degree of vascular selectivity than nifedipine (Ljung, 1980). Early data on this agent suggest that it may produce acute haemodynamic improvements in heart failure when given acutely
(Culling et al., 1984) and may improve exercise tolerance in the longer term (Timmis et al., 1984a,b).

\section{Conclusions}

Vasodilators are now an important part of the treatment of the patient with more resistant cardiac failure. Calcium antagonists could be considered a reasonable choice in this situation since they may exert a beneficial effect not only on the haemodynamic disturbances encountered in heart failure but also on the underlying disease process particularly if it is ischaemic heart disease (Kendall \& Horton, 1985) or hypertension. Furthermore they may be expected to correct the deleterious compensatory responses of fluid retention and vasoconstriction with the resulting impairment of tissue perfusion. They may also be able to correct some of the compensatory cardiomegaly (Strauer et al., 1984; Friberg, 1985).

The situation has been reached where the concept of calcium antagonists being potentially useful in the treatment of heart failure has to be accepted. It is now necessary to determine their place in management. Much more data is required and this must be based on good controlled trials which are currently lacking (Lipkin \& Poole-Wilson, 1985). In addition there must be studies comparing them with the more conventional vasodilators and more particularly with the angiotensin converting enzyme inhibitors.

\section{References}

ANTMAN, E., MULLER, J., GOLDBERG, S., MACALPIN, R., RUBEWFIRE, M., TABATZNIK, B., LIANG, C., HEUPLER, F., ACHUFF, S., REICHEK, N., GELTMAN, E., KERIN, N.Z., NEFF, R.K. \& BRAUNWALD, E. (1980). Nifedipine therapy for coronary artery spasm. New England Journal of Medicine, 302, 1269.

BELL, A.J. \& LINDNER, A. (1984). Effects of verapamil and nifedipine on renal function and haemodynamics in the dog. Renal Physiology, 7, 329.

BELLOCCI, F., ANSALONE, G., SCABBIA, E., AFFINITO, V., SANTARELLI, P., LOPERFIDO, F. \& ZECCHI, P. (1981). Sustained beneficial effect of nifedipine in chronic refractory heart failure. American Journal of Cardiology, 47, 407.

BOURASSA, M.G., COTE, P., THEROUX, P., TUBAU, J.F., GENAIN, C. \& WATERS, D.D. (1980). Haemodynamics and coronary flow following diltiazem administration in anaesthetised dogs and in humans. Chest, 78, 224S.

BOUTLES, M., BALA SUBRAMANIAN, V., DAVIES, A. \& RAFTERY, E. (1983). Double blind randomised cross over trial of verapamil and propranolol in chronic stable angina. American Heart Journal, 106, 1297.

BROOKS, N., CATTELL, M., PIDGEON, J. \& BALCON, R. (1980). Unpredictable response to nifedipine in severe heart failure. British Medical Journal, 281, 1324.

BUHLER, F.R., HULTHEN, U.L., KIOWSKI, W. \& BOLLI, P.

(1982). Greater antihypertensive efficacy of the calcium channel inhibitor verapamil in older and low renin patients. Clinical Science, 63, 439S.

CHEW, C.Y.C., HECHT, H.S., COLLETT, J.T., MCALLISTER, R.G. \& SINGH, B.N. (1981). Influence of severity of ventricular dysfunction on hemodynamic responses to intravenously administered verapamil in ischemic heart disease. American Journal of Cardiology, 47, 917.

CLUSIN, W.T., BRISTOW, M.R., BAIM, D.S., SCHROEDER, J.S., JAILLON, P., BRETT, P. \& HARRISON, D.C. (1982). The effects of diltiazem and reduced serum ionised calcium on ischemic ventricular fibrillation in the dog. Circulation Research, 50, 58.

CULLING, W., RUTTLEY, M.S.M. \& SHERIDAN, D.J. (1984). Acute haemodynamic effects of felodipine during betablockade in patients with coronary artery disease. British Heart Journal, 52, 431.

DALE, J., LANDMARK, K.H. \& MYHRE, E. (1983). The effects of nifedipine, a calcium antagonist, on platelet function. American Heart Journal, 105, 103.

ELKAYAM, U., WEBER, L., TORKAN, B., BERMAN, D. \& RAHIMITOOLA, S.H. (1983). Acute hemodynamic effect of oral nifedipine in severe chronic congestive heart failure. American Journal of Cardiology, 52, 1041.

ELKAYAM, U., WEBER, L., MCKAY, C. \& RAHIMTOOLA, S. 
(1985). Spectrum of acute hemodynamic effects of nifedipine in severe congestive heart failure. American Journal of Cardiology, 56, 560.

ELLRODT, G., CHEW, C.Y.C. \& SINGH, B. (1980). Therapeutic implications of slow-channel blockade in cardiocirculatory disorders. Circulation, 62, 669.

FAGBEMI, O. \& PARRATT, J.R. (1981). Calcium antagonists prevent early post-infarction ventricular fibrillation. European Journal of Pharmacology, 75, 179.

FERLINZ, J., EASTHOPE, J.L. \& ARONOW, N.S. (1979). Effects of verapamil on myocardial performance in coronary disease. Circulation, 59, 313.

FERLINZ, J. \& CITRON, P.D. (1983). Hemodynamic and myocardial performance characteristics after verapamil use in congestive heart failure. American Journal of Cardiology, 51, 1339.

FRANCIOSA, J.A., WILEN, M., ZIESCHE, S. \& COHN, J.N. (1983). Survival in men with severe chronic left ventricular failure due to either coronary heart disease or idiopathic dilated cardiomyopathy. American Journal of Cardiology, 51,831 .

FRIBERG, P. (1985). Structural and functional adaptation in the rat myocardium and coronary vascular bed caused by changes in pressure and volume overload. Acta Physiologica Scandinavica, 124, (Suppl. 540).

GERSTENBLITH, G., OUYANG, P., ACHUFF, S.C., BULKLEY, B.H., BECKER, L.C., MELLITS, E.D., BAUGHMAN, K.L., WEISS, J.L., FLAHERTY, J.T., KALLMAN, C.H., LLEWELLYN, M. \& WEISFELDT, M.L. (1982). Nifedipine in unstable angina - a double-blind randomised trial. New England Journal of Medicine, 306, 885.

GOULD, B.A., MANN, S., KIESO, H., SUBRAMANIAN, V.B. \& RAFTERY, E.B. (1982). The 24 hour intra-arterial ambulatory profile of blood pressure reduction with verapamil. Circulation, 65, 22.

GUAZZI, M.D., CIPOLLA, C., BELLA, P.D., FABBIOCCHI, F., MONTROSI, P. \& SGANZERLA, P. (1984). Disparate unloading efficacy of the calcium channel blockers, verapamil and nifedipine, on the failing hypertensive left ventricle. American Heart Journal, 108, 116.

HORNUNG, R.S., GOULD, B.A., JONES, R.I., SONECHA, T.N. \& RAFTERY, E.B. (1983). Nifedipine tablets for systemic hypertension: a study using continuous ambulatory intraarterial recording. Circulation Research, 51, 1323.

JOHNS, E.J. (1985). The influence of diltiazem and nifedipine on renal function in the rat. British Journal of Pharmacology, 84, 707.

JOHNSTON, D.L., LESOWAY, R., HUMEN, D.P. \& KOSTUK, W.J. (1985). Clinical and hemodynamic evaluation of propranolol in combination with verapamil, nifedipine and diltiazem in exertional angina pectoris. American Journal of Cardiology, 55, 680.

KATES, R.E., KEEFE, L.D. \& SCHWARTZ, J. (1981). Verapamil disposition kinetics in chronic atrial fibrillation. Clinical Pharmacology and Therapeutics, 30, 44.

KATZ, A.M., HAGER, W.D., MESSINEO, F.C. \& PAPANO, A.J. (1984). Cellular actions and pharmacology of the calcium channel blocking drugs. American Journal of Medicine, 77 (2B), 2.

KENDALL, M.J. \& HORTON, R.C. (1985). Are calcium antagonists cardioprotective? Journal of the Royal College of Physicians (London), 19, 85.

LIPKIN, D.P. \& POOLE-WILSON, P.A. (1985). Treatment of chronic heart failure - a review of recent drug trials. British Medical Journal, 291, 993.

LJUNG, B. (1980). Vascular versus myocardial selectivity in vitro of $\mathrm{H} 154 / 82$, a new dihydropyridine. Blood Vessels, 17 , 154.

LUDBROOK, P.A., TIEFENBRUNN, A.J., REED, F.R. \& SOBEL, B.E. (1982). Acute hemodynamic responses to sublingual nifedipine: dependence on left ventricular function. Circulation, 65, 489.

MAGORIEN, R.D., LEIER, C.V., KOLIBASH, A.J., BARBUSH, T.J. \& UNVERFERTH, D.V. (1984). Beneficial effects of nifedipine on rest and exercise myocardial energetics in patients with congestive heart failure. Circulation, 70, 884 .

MATERNE, P., LEGRAND, V., VANDORMAEL, M., COLLIGNON, P. \& KULBERTUS, H.E. (1984). Hemodynamic effects of intravenous diltiazem with impaired left ventricular function. American Journal of Cardiology, 54, 733.

MATSUI, S., MURKAMI, E., TAKEKOSHI, N., HIRAMARU, Y., MURAKAMI, H., KIJANO, E., MATSUYA, K., SAGA, T., NOMURA, M., FUJITA, S. \& TSUJI, S. (1979). Haemodynamic effects of sublingual nifedipine in congestive heart failure. Japanese Circulation Journal, 43, 1081.

MATSUMOTO, S., ITO, T., SADA, T., TAKAHASHI, M., SU, K.M., UEDA, A., OKABE, F., SATO, M., SEKINE, I. \& ITO, Y. (1980). Hemodynamic effects of nifedipine in congestive heart failure. American Journal of Cardiology, 46, 476.

OPIE, L.H. (1984). Calcium antagonists. Mechanisms, therapeutic indications and reservations; A Review. Quarterly Journal of Medicine, 209, 1.

PACKER, M. (1985). Vasodilator therapy for primary pulmonary hypertension. Annals of Internal Medicine, 103, 258.

PETRU, M., CRAWFORD, M., SORENSEN, S., CHAUDHURI T., LEVINE, S. \& O'ROURKE, R. (1983). Short and long term efficacy of high-dose oral diltiazem for angina due to coronary artery disease: A placebo-controlled, double blind cross-over study. Circulation, 68, 139.

ROSING, D.R., CONDIT, J.R., MARON, B.J., KENT, K.M., LEON, M.B., BONOW, R.D., LIPSON, L.C. \& EPSTEIN, S.E. (1981). Verapamil therapy: a new approach to the pharmacologic treatment of hypertrophic cardiomyopathy: III. Effects of long-term administration. American Journal of Cardiology, 48, 548.

SCHAMROTH, L. (1980). The clinical use of intravenous verapamil. American Heart Journal, 100, 1070.

SPEDDING, M. (1985). Calcium antagonist subgroups. Trends in Pharmacological Science, 6, 109.

STRAUER, B.E., MAHMOUD, M.A., BAYER, F., BOHN, I. \& MOTZ, U. (1984). Reversal of left ventricular hypertrophy and improvement of cardiac function in man by nifedipine. European Heart Journal, 5 (Suppl. F), 53.

STRAUSS, W.E. \& PARISI, A.F. (1985). Superiority of combined diltiazem and propranolol therapy for angina pectoris. Circulation, 71, 951.

STURANI, C., BASSEIN, L., SCHIARINA, M. \& GURELLA, G. (1984). Oral nifedipine in chronic cor pulmonale, secondary to severe chronic obstructive pulmonary disease (COPD). Short and long term haemodynamic effects. Chest, 84, 135.

SUBRAMANIAN, V.B., BOWLES, M.J., KHURMI, N.S., DAVIES, A.B. \& RAFTERY, E.B. (1982). Rationale for the choice of calcium antagonists in chronic stable angina: an objective double-blind placebo controlled comparison of 
nifedipine and verapamil. American Journal of Cardiology, 50, 1173.

THEROUX, P., WATERS, D.D. \& LATOUR, J.G. (1982). Clinical manifestations and pathophysiology of myocardial ischemia with special reference to coronary artery spasm and the role of slow channel calcium blockers. Progress in Cardiovascular Disease, 25, 157.

TIMMIS, A.D., KENNY, J.F., SMYTH, P., CAMPBELL, S., KERKEZ, S.A. \& JEWITT, D.E. (1984a). Restoration of normal reflex responses to orthostatic stress during felodipine therapy in congestive heart failure. Cardiovascular Research, 18, 613.
TIMMIS, A.D., CAMPBELL, S., MONAGHAM, M.J., WALKER, L. \& JEWITT, D.E. (1984b). Acute haemodynamic and metabolic effects of felodipine in congestive heart failure. British Heart Journal, 51, 445.

WALLER, D.G., NICHOLSON, H.P. \& ROATH, S. (1984). The acute effects of nifedipine on red cell deformability in angina pectoris. British Journal of Clinical Pharmacology, 17, 133.

WALSH, R.A., PORTER, C.B., STARLING, M.R. \& O'ROURKE, R.A. (1982). Salutary hemodynamic effects of intravenous and oral diltiazem in severe congestive heart failure. Circulation, 66 (Suppl. II), 138. 